\title{
Coronavirus Disease-19 and Dentistry: A Review
}

\author{
Fareedi Mukram Ali ${ }^{1 *}$, Kishor Patil $^{2}$, Elnur Ibrahim Albashir ${ }^{1}$, Abdulhamid Aidarous Alamir $^{1}$ \\ ${ }^{1}$ College of Dentistry, Oral and Maxillofacial Surgery Jazan, Jazan, Saudi Arabia; ${ }^{2}$ SMBT Dental College and Hospital and Post \\ Graduate Research Center, Oral Pathology and Microbiology, Sangamner, Maharashtra, India
}

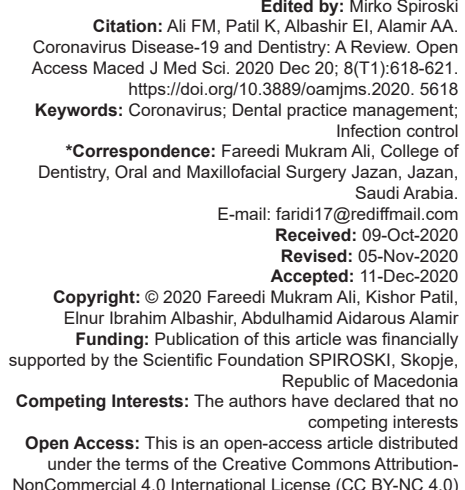
Citation: Ali FM, Patil K, Albashir EI, Alamir AA Coronavirus Disease-19 and Dentistry: A Review. Open Access Maced J Med Sci. 2020 Dec 20; 8(T1):618-621. https://doi.org/10.3889/oamims.2020.5618 Keywords: Coronavirus; Dental practice management; Infection control *Correspondence: Fareedi Mukram Ali, College of Dentistry, Oral and Maxillofacial Surgery Jazan, Jazan, E-mail: faridi17@rediffmail.com Received: 09-Oct-2020 Revised: 05-Nov-2020 Accepted: 11-Dec-2020
Copyright: $\odot 2020$ Fareedi Mukram Ali, Kishor Patil,
Elnur lbrahim Albashir, Abdulhamid Aidarous Alamir Enur Ibrahim Albashir, Abdulhamid Aidarous Alamir
Funding: Publication of this article was financially Funding: Publication of this article was financially
supported by the Scientific Foundation SPIROSKI, Skopje, Republic of Macedonia Competing Interests: The authors have declared that no
competing interests Open Access: This is an open-access article distributed under the terms of the Creative Commons Attribution-

\begin{abstract}
Novel coronavirus ( $\mathrm{nCoV}$ ) is a novel form of virus with a new strain identified recently in humans. Common clinical signs and symptoms primarily consist of fever, cough, and breathing difficulties. In severe cases, it can results in pneumonia, severe acute respiratory syndrome, kidney failure, and even death. It is important to follow al infection control measures in prevention of the $\mathrm{nCoV}$ from spreading and controlling the epidemic situation. The risk of cross infection can be high between dental practitioners and patients due to the features of dental clinica settings. Here, we are summarizing the $\mathrm{nCoV}$ related information and infection control measures to be followed in dental practice.
\end{abstract}

\section{Introduction}

The pandemics of coronavirus disease (COVID-19) started from Wuhan, China, last December and Chinese Center for Disease Control and Prevention [1] on January 8, 2020, officially announced a novel form of coronavirus (nCoV) as the causative agent. It was first named as 2019-nCoV, but later officially as severe acute respiratory syndrome nCOV 2 (SARS-CoV-2) [2]. Now, it has become a major health problem not only for China but also majority of countries around the world [3]. The World Health Organization on January 30 announced that COVID-19 outbreak is a public health emergency of international concern [2], [4].

\section{Characteristics of Virus}

SARS-CoV-2 is a zoonotic virus [2]. nCoVs are from the family of Coronaviridae, of the order Nidovirales. It has genome of large, single, and plusstranded RNA [5], [6]. There are four genera of nCoVs, namely, $\alpha-\mathrm{CoV}, \beta-\mathrm{CoV}, \gamma-\mathrm{CoV}$, and $\delta$-CoV. The $\alpha-\mathrm{CoV}$ and $\beta$-CoV mainly infect the respiratory, gastrointestinal, and central nervous system of humans and mammals, while $\gamma$-CoV and $\delta$-CoV mainly infect the birds [7].

SARS-CoV and the Middle East respiratory syndrome CoV explored in 2002-2003 and in 2012, respectively, belong to the $\beta-\mathrm{CoV}$. The virus explored in Wuhan, SARS-CoV-2, also belongs to the $\beta$-CoV11. The genome nucleotide sequence uniqueness was $96.2 \%$ between nCoV detected in the bat Rhinolophus affinis from Yunnan Province, China, and SARS-CoV-2, indicating the natural host of SARS-CoV-2 is the $R$. affinis bat [7].

However, the genome sequence similarity was $99 \%$ to the $\mathrm{nCoV}$ isolated from pangolins, indicating that these as the most likely intermediate host of SARSCoV-2 [2], [7].

\section{Incubation Period}

An average of 5-6 days is the estimated incubation period of COVID-19. There is evidence that it might be as long as 14 days, which is now the universally adopted duration for medical surveillance 
and quarantine of potentially exposed or exposed persons [2].

\section{People at High Risk of Infection}

1. Peoples of all ages are usually susceptible to COVID-19. Healthcare workers and other individuals who are in close contact with patients of symptomatic and asymptomatic COVID-19 are at higher risk of SARS-CoV-2 infection [2]

2. Patients with most severe disease were more likely to have hypertension respiratory disease and cardiovascular disease [8]

3. In other studies, obesity and smoking were associated with increased risks [9], [10].

\section{Common Symptoms}

The characteristics symptoms of the patients were fever, cough, and myalgia or fatigue with abnormal chest computed tomography (CT). The less common symptoms were sputum production, headache, hemoptysis, and diarrhea [7].

\section{Oral Manifestations}

\begin{tabular}{ll}
\hline $\begin{array}{l}\text { Ulcerations (unilateral palatal ulcerations) } \\
\text { or blistering in the oral cavity }\end{array}$ & $\begin{array}{l}\text { Reported as possible signs and symptoms } \\
\text { in confirmed case of COVID-19 by Sinadinos } \\
\text { and Shelswell [11] }\end{array}$ \\
$\begin{array}{l}52 \% \text { - changes in taste sensation } 56.25 \% \\
- \text { dry mouth } 11 \% \text { - pain in muscles of } \\
\text { mastication }\end{array}$ & $\begin{array}{l}\text { Reported as major changes in study by } \\
\text { Biadsee et al. [12] }\end{array}$ \\
Necrotizing periodontal disease & $\begin{array}{l}\text { Patel and Woolley in their letter to the editor } \\
\text { proposed this can be an oral manifestation in } \\
\text { patients with COVID-19 [13] } \\
\text { Soares et al. [14] and } \\
\text { Chaux-Bodard et al. [15] in their letter to the } \\
\text { editor marked in patients of COVID- } 19 \\
\text { Reported by Pedrosa et al. [16] }\end{array}$ \\
Oral reddish lesions and ulcerations & \\
$\begin{array}{l}\text { Smell and taste loss (chemosensory } \\
\text { dysfunction) }\end{array}$ & \\
\hline
\end{tabular}

\section{Source of Transmission}

1. Patients with symptomatic COVID-19 have been the main source of transmission [2]

2. Asymptomatic patients in their incubation period [2].

\section{Epidemiology}

- Interpersonal transmission occurs mainly through respiratory droplets and contact transmission [2], [7]

- $\quad$ Studies have suggested that 2019-nCoV may be airborne through aerosols produced during medical procedures. However, the aerosol transmission route and the fecaloral transmission route worried by the public still required to be further studied and confirmed [2], [7].

\section{Spread in Dental Clinics}

Eyes, nose, and oral cavity as the "T" zone in the maxillofacial region being the main entry for the virus into an individual, alerts all dental professionals while doing any procedures [17]

Dental care settings invariably carry the increased risk of 2019-nCoV infection due to the following reasons (Table 1 and Figure 1).

Table 1: Risk factors in dental clinic settings

\begin{tabular}{l}
\hline Risk factors \\
Have more face-to-face communication with patients [2],[7] \\
Everyday exposure to saliva, blood, and other body fluids [2],[7] \\
Handling of the sharp instruments [2],[7] \\
Contact with droplets and aerosols [18] \\
Direct contact with patient materials [19] \\
Indirect contact with contaminated instruments and/or environmental surfaces [20] \\
\hline
\end{tabular}

Indirect contact with contaminated instruments and/or environmental surfaces [20]

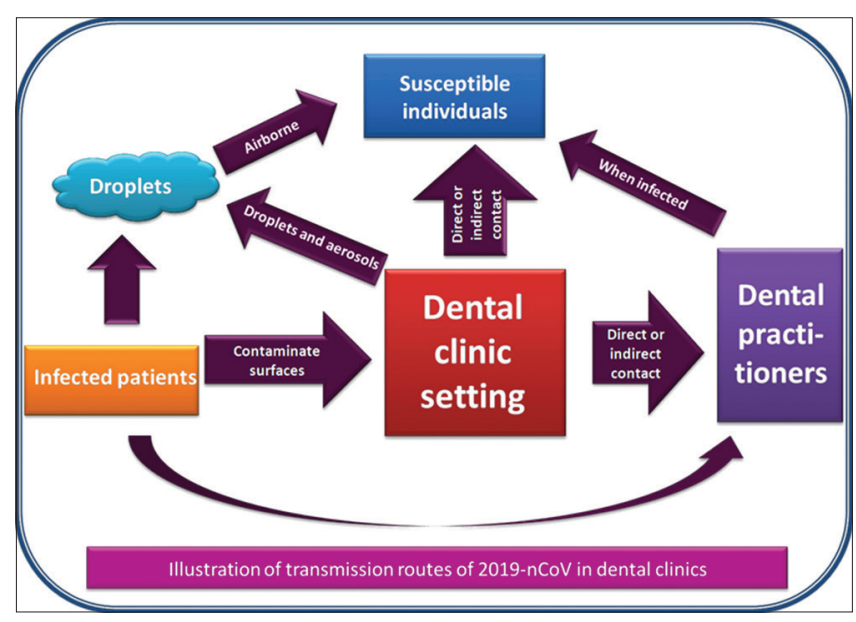

Figure 1: Illustration of transmission routes of 2019-nCoV in dental clinics

\section{Infection Control in Dental Practice}

In the early stages of COVID-19, the viral load in the saliva was constantly found high than that in the 
region of oropharynx. The SARS-CoV-2 viral load in the saliva can be effectively reduced for a short period of time with chlorhexidine mouthwash [21].

Alharbi et al. [22] classified therapeutic dental procedures into five groups: Emergencies, emergencies manageable through invasive or non-invasive procedures (minimum aerosol), non-emergencies, and elective treatments, depending on the dentist.

Following are the suggested measures to avoid spread of infection in dental clinics (Table 2).

\section{Table 2: Infection control in dental practice}

Infection control in dental practice

Patient evaluation: Identify a suspected case of COVID-19 [7]

Measurement of the body temperature: Should be measured in the first place using a

contact-free forehead thermometer [7]

Screening: With the help of questionnaire [7]

Mouth rinse: preoperational antimicrobial mouth rinse with $1 \%$ hydrogen peroxide or $0.2 \%$ povidone is generally believed to reduce the number of oral microbes [7]

$X$ rays: Orthopantomographs $(\mathrm{OPG})$ or lateral oblique views may be considered instead

of intraoral radiographs (IOPA) when required [23]

Hand hygiene: Good hand hygiene is of the utmost importance [7]

Dental professionals should avoid touching their own eyes, mouth, and nose [7], [24]

PPE: Protective eyewear, masks, gloves, caps, face shields, and protective outwear, is strongly recommended [7]

Dispensing instruments and materials: Should be done just before treatment. This

prevents particles from settling on the surfaces [25]

Rubber dams: Significantly minimize the production of saliva- and blood- contaminated aerosol or spatter [7]

Anti-retraction high-speed dental hand piece: Can significantly reduce the backflow of oral microorganisms into the tubes of the hand piece and dental unit as compared with the hand piece without anti-retraction function [7], [26]

Impression making: Very sensitive patients may be anesthetized or sedated before taking impressions to control gag reflex [27], [28]

High volume evacuation: To remove infectious droplets at the source as soon as they are emitted. This minimize or prevent their dispersion in the air [29]

Disinfection of surfaces: Effective and strict disinfection measures using hospital-grade disinfectants after each patient in clinic setting [7], [30]

Sterilization of instruments: Is must for all the instruments [7]

Public areas such as door handles, chairs, and desks and elevators should be frequently disinfected [7]

Management of medical waste: Double-layer yellow color medical waste package bags and "gooseneck" ligation should be used [7]

\section{Diagnosis and Laboratory Tests}

1. The diagnosis of COVID-19 can be based on a combination of [31]

\section{- $\quad$ Clinical symptoms}

- $\quad$ CT imaging findings ( seen in severe infection patients), and

- Laboratory tests: For example, reverse transcriptase polymerase chain reaction (RT-PCR) tests on respiratory tract specimens using nasopharyngeal, oropharyngeal, and blood samples.

2. It should be mentioned that a single negative RT-PCR test result from suspected patients does not rule out infection. Clinically, we should be alert of patients with an epidemiologic history, COVID-19-related symptoms, and/or positive CT imaging results [31]

3. Saliva was found to be even more sensitive for SARS-CoV-2 detection in COVID-19 patients than nasopharyngeal swabs [32].

\section{Treatment}

In the present scenario, there has been no confirmation from randomized controlled trials to suggest any particular anti-nCoV treatment. Thus, the management consists of measures such as controlling the source of infection; lower the risk of infection transmission; and also provide early diagnosis, isolation, and supportive care for affected patients [9].

\section{Conclusion}

Although dental clinics have been closed during the epidemic, a large number of emergency patients need dental treatment. We have summarized the virology of 2019-nCoV, possible transmission routes and its control in dental clinics.

\section{References}

1. Li Q, Guan X, Wu P, Wang X, Zhou L, Tong Y, et al. 2020. Early transmission dynamics in Wuhan, China, of novel coronavirusinfected pneumonia. N Engl J Med. 2020;382:1199-207.

2. Phelan AL, Katz R, Gostin LO. The novel coronavirus originating in Wuhan, China: Challenges for global health governance. JAMA. 2020;323(8):709-10. https://doi.org/10.1001/ jama.2020.1097

PMid:31999307

3. Meng L, Hua F, Bian Z. Coronavirus disease 2019 (COVID-19): Emerging and future challenges for dental and oral medicine. J Dent Res. 2020;99(9):481-7. https://doi. org/10.1177/0022034520914246

PMid:32162995

4. Aldahlawi S, Afifi IK. COVID-19 in dental practice: Transmission risk, infection control challenge, and clinical implication. Open Dent J. 2020;14:348-54. https://doi. org/10.2174/1874210602014010348

5. Fehr AR, Perlman S. Coronaviruses: An overview of their replication and pathogenesis. Methods Mol Biol. 2015;1282:1-23. PMid:25720466

6. Gorbalenya AE, Enjuanes L, Ziebuhr J, Snijder EJ. Nidovirales: Evolving the largest RNA virus genome. Virus Res. 2006;117(1):17-37. https://doi.org/10.1016/j. virusres.2006.01.017

PMid: 16503362

7. Peng XX, Xu X, Li Y, Cheng L, Zhou X, Ren B. Transmission routes of 2019-nCoV and controls in dental practice. Int J Oral Sci. 2020;12:9. https://doi.org/10.1038/s41368-020-0075-9

8. Yang J, Zheng Y, Gou X, Pu K, Chen Z, Guo Q, et al. Prevalence of comorbidities and its effects in patients infected with SARSCoV-2: A systematic review and meta-analysis. Int J Infect Dis. 2020;94:91-5. https://doi.org/10.1016/j.ijid.2020.03.017 PMid:32173574

9. Wang D, Hu B, Hu C, Zhu F, Liu X, Zhang J, et al. Clinical 
characteristics of 138 hospitalized patients with 2019 novel coronavirus-infected pneumonia in Wuhan, China. JAMA. 2020;323(11):1061-9. https://doi.org/10.1001/jama.2020.1585 PMid:32031570

10. Jordan RE, Adab P, Cheng KK. Covid-19: Risk factors for severe disease and death. BMJ. 2020;368:m1198. https://doi. org/10.1136/bmj.m1198

PMid:32217618

11. Sinadinos A, Shelswell. Oral ulceration and blistering in patients with COVID-19. Evid Based Dent 2020;21(2):49. https://doi.org/10.1038/s41432-020-0100-z PMid:32591655

12. Biadsee A, Biadsee A, Kassem F, Dagen O, Masarwa $S$, Ormianer Z. Olfactory and oral manifestations of COVID-19: Sex-related symptoms-a potential pathway to early diagnosis. Otolaryngol Head Neck Surg. 2020;163(4):722-8. https://doi. org/10.1177/0194599820934380 PMid:32539587

13. Patel J, Woolley J. Necrotizing periodontal disease: Oral manifestation of COVID-19. Oral Dis. 2020;???:1-2. https://doi. org/10.1111/odi.13462 PMid:32506662

14. Soares CD, Carvalho RA, Carvalho KA, Carvalho MG Almeida OP. Letter to editor: Oral lesions in a patient with Covid-19. Med Oral Patol Oral Cir Bucal. 2020;25(4):e563-4. https://doi.org/10.4317/medoral.24044 PMid:32520921

15. Chaux-Bodard AG, Deneuve S, Desoutter A. Oral manifestation of Covid-19 as an inaugural symptom? J Oral Med Oral Surg. 2020;26(2):18. https://doi.org/10.1051/mbcb/2020011

16. Pedrosa MS, Sipert CR, Nogueira FN. Salivary glands, saliva and oral findings in COVID-19 infection. Pesqui Bras Odontopediatr Clín Integr. 2020;20(Supp 1):e0104. https://doi. org/10.1590/pboci.2020.112

17. Pankajakshi BK, Ali FM, Raviya MP. Adapting our professional life with corona: A challenge that oral \& maxillofacial surgeons are bound to accept. J Res Adv Dent. 2020;10(3):129-33.

18. Kampf G, Todt D, Pfaender S, Steinmann E. Persistence of coronaviruses on inanimate surfaces and their inactivation with biocidal agents. J Hosp Infect. 2020;104(3):246-51. https://doi. org/10.1016/j.jhin.2020.01.022 PMid:32035997

19. Chen J. Pathogenicity and transmissibility of 2019-nCoV-a quick overview and comparison with other emerging viruses. Microb Infect. 2020;22(2):69-71. https://doi.org/10.1016/j. micinf.2020.01.004

20. Yoon JG, Yoon J, Song JY, Yoon SY, Lim CS, Seong H, et al. Clinical significance of a high SARS-CoV-2 viral load in the saliva. J Korean Med Sci. 2020;35(20):e195. https://doi. org/10.3346/jkms.2020.35.e195

PMid:32449329
21. Liu L, Wei Q, Alvarez X, Wang H, Du Y, Zhu H, et al. Epithelial cells lining salivary gland ducts are early target cells of severe acute respiratory syndrome coronavirus infection in the upper respiratory tracts of rhesus macaques. J Virol. 2011;85(8):402530. https://doi.org/10.1128/jvi.02292-10

PMid:21289121

22. Alharbi A, Alharbi $S$, Alqaid S. Guidelines for dental care provision during the COVID-19 pandemic. Saudi Dent J. 2020;32(4):181-6. https://doi.org/10.1016/j.sdentj.2020.04.001 PMid:32292260

23. Zaki AM, Van Boheemen S, Bestebroer TM, Osterhaus AD, Fouchier RA. Isolation of a novel coronavirus from a man with pneumonia in SaudiArabia. NEngl J Med. 2012;367(19):1814-20. https://doi.org/10.1056/nejmoa1211721 PMid:23075143

24. Kochhar AS, Bhasin R, Kochhar GK, Dadlani H. COVID-19 pandemic and dental practice. Int J Dent. 2020;2020:8894794. https://doi.org/10.1155/2020/8894794

25. Thabet F, Chehab M, Bafaqih H, Al Mohaimeed S. Middle East respiratory syndrome coronavirus in children. Saudi Med J. 2015;36(4):484-6. https://doi.org/10.15537/smj.2015.4.10243 PMid:25828287

26. Villani FA, Aiuto R, Paglia L, Re D. COVID-19 and dentistry: Prevention in dental practice, a literature review. Int $\mathrm{J}$ Environ Res Public Health. 2020;17(12):4609. https://doi.org/10.3390/ ijerph17124609 PMid:32604906

27. Whaites E. Essentials of Dental Radiography and Radiography $2^{\text {nd }}$ ed. Edinburgh: Churchill-Livingstone; 1996. p. 107-13.

28. Robb ND, Crothers AJ. Sedation in dentistry. Part 2: Management of the gagging patient. Dent Update. 1996;23(5):182-6. PMid:8948179

29. Li RW, Leung KW, Sun FC, Samaranayake LP. Severe acute respiratory syndrome (SARS) and the GDP. Part II: Implications for GDPs. Br Dent J. 2004;197(3):130-4. https://doi.org/10.1038/ sj.bdj.4811522 PMid: 15311240

30. Wenzel RP, Edmond MB. Managing SARS amidst uncertainty. N Engl J Med. 2003;348(20):1947-8. https://doi.org/10.1056/ nejmp030072 PMID: 12748313

31. Sabino-Silva R, Jardim AC, Siqueira L. Coronavirus COVID-19 impacts to dentistry and potential salivary diagnosis. Clin Oral Investig. 2020;24(4):1619-21. https://doi.org/10.1007/ s00784-020-03248-x PMid:32078048

32. Wyllie AL, Fournier J, Casanovas-Massana A, Campbell M, Tokuyama M, Vijayakumar P, et al. Saliva is More Sensitive for SARS-CoV-2 Detection in COVID-19 Patients than Nasopharyngeal Swabs. New York: Medrxiv; 2020. https://doi. org/10.3410/f.737795545.793573919 